\title{
Review, deliberate fault in the field of civil liability in Iranian and French law
}

\author{
Akbar Bashiri ${ }^{*}$ \\ Khosrow Khosrowi ${ }^{2}$ \\ Kazem Nasiri Chianeh ${ }^{3}$
}

\begin{abstract}
Iranian jurisprudence and law are based on the principle of the humiliation responsibility and the absolute responsibility is familiar so there is a need for clear legislation. Humiliate is the victim and wastage of human behavior in the external circumstances of the incident. Also, by accepting the idea of a kind of humiliation in Iranian and French people the lack of clear non-point like maniacs are also responsible under the circumstance. Humiliation is divided into a different variety, sometimes based on material element (action and omission), sometimes based on spiritual element (contempt intentional and unintentional) are divided. Due to its deliberate humiliation in the context of the basic conditions is important and the intention intentional infliction of humiliation decisions. Sometimes heavy fault committed and the circumstances of the loss are presumptively for the detection of deliberate humiliation. The tools created the loss; the responsibility is with the conventional and original tools with the community in creating losses, the dividing responsibility should be on the effect rate of the tools and the Article 526 F.M.I are mere observer that the affecting any of the tools are equal. Force majeure objective or absolute responsibility such as anger does not read in responsibility but assuming responsibility based on humiliation and contempt Read exempt returns claim of responsibility.
\end{abstract}

Keywords: Civil liability, humiliation, deliberate humiliation, Responsibility based on humiliation

\section{Introduction}

Despite the various views on the basis of civil liability, the fault is still considered as a fundamental basis in this regard, and it has sometimes been claimed that other grounds are defects of the theory of fault. The fault is also divided into different categories in the course of time and with the advent of science and technology. In some legal systems as well as in Iran's rights, although the only basis for liability lies not at the loss of the subject; but at least one of the important bases of responsibility for the fault can be considered to be harmful to the subject. Consequently, it can be

\footnotetext{
${ }^{1}$ Corresponding Author: Assistant Professor, Department of Law, Maragheh Branch, Islamic Azad University, Maragheh, Iran akbarbashiri@yahoo.com

2 PhD Student, Department of Law, Maragheh Branch, Islamic Azad University, Maragheh, Iran Kosrowi@gmail.com

${ }^{3}$ PhD Student, Department of Law, Maragheh Branch, Islamic Azad University, Maragheh, Iran Kazim.nasiri2013@gmail.com
} 
said that in Iranian law it is true that it does not have much to do with the loss of fault, but in cases of misconduct, it is the pivot of responsibility.

\section{Problem statement}

In many of the books titled Civil Responsibility, In addition to the existence of harm and the perpetration of harmful acts and the causal relationship, in the expression of its components, the fault is mentioned as an independent and separate pillar. This phrase means that if a person makes a harmful relationship by causing the damage to the individual, he is not responsible. Because although all of these elements are proven and certain, that a person by his actions has caused damage to another. But this alone was not enough, because his fault was not proved (Qadisi, 2011).

\section{Background research}

There has been a lot of research done at home and abroad on intentional fault of civil responsibility. Here are some of the researches and the results we get from them:

In 2005, Kazemi wrote a research entitled "The Effects of Laid Custody on Civil Liability", published in Number 28 of Quarterly Research.

In 2010, Qadisi wrote a study titled "The Place of Fault in Civil Responsibility", published in No. 31 of the Islamic-Islamic Research Law Research (Private Law).

In 2011, Raie and Yousefian wrote a study titled "Fault in Civil Liability and Justice," published in the first issue of the Journal of Legal Literature.

\section{Aims}

1. Investigating and expressing various aspects of deliberate blame on civil liability in Iranian and French law.

2. Comparison and accommodation of various aspects of deliberate blame on civil liability in Iran and France.

\section{The concept of fault}

The definition of the blame between the scholars is a matter of dispute. Pellanion, professor of French law, said: The fault is a breach of an obligation that existed beforehand. This definition is true, however, it does not provide a clear benchmark on how to distinguish between general and general obligations to which the general duty of care and care refers and it is not clear at what time the general obligation of precaution and care is violated, the person is guilty of gross negligence or negligence. 
The traditional and traditional definition of fault is the illegitimate illegal act that can be attributed to the agent, sometimes construed as a blaming act. Therefore, the definition is not considered a fault if the act is consistent with the law and is not blamed; With this conclusion, it must be agreed, but what is implied in this definition is that, first, this definition does not provide an answer to this question: Which of the acts that humans perform and do not conform to the law is a fault? Secondly, according to this definition, only actions and verbs are considered to be a fault that can be suited to a person and it means that if a person does not have the power to understand his current ugliness, he will not be blamed. While in the twentieth century the culprit has found a certain concept. This means that the violation of the standard behavior is the criterion of fault and that it is no longer necessary for the person's verb to be blameworthy and that the psychological and internal conditions of the harmful factor should be investigated and that, therefore, the minor and the innocent may be blamed. The definition of some of the French professors that is also acceptable in our law is that: "A fault is a mistake in the behavior of a prudent person who is in the same situation as a foreigner". Thus, it can be said that the fault is: violation of normal human behavior.

Articles from 951 to 953 compatible with this definition. Article 953 of the Criminal Code It stipulates: The fault is due to congestion. Against Article 951 of this Law: The offense is a violation of the limits of the permission or is customary in relation to the property or right. Article 952 also defines the scope. Extinguishment is the abandonment of a practice that is contractually or conventionally necessary to maintain the property. So it can be said that the fault is: Performing an action that one should not commit (abusive) or abandoning what a person should do (Wastage).

\section{Elements of the fault}

In the past, French law saw the blame for two elements: One of the positive or negative verbs was considered as the objective and material element of the fault, and the other was a mental attribution that was the personal and spiritual element of the fault; In that sense, the cause of the damage was considered to be the fault of such action, knowing that its behavior was abusive and blameworthy. In other words, he freely and fully understands the behavior. Thus, they were not underage, because they did not have the ability to understand separation, and they did not have a civil liability.

The condition of attribution from France in the 1930s was strongly criticized by the proponents of the theory of guilty misconduct. They consider rape of normal human behavior or a breach of a duty arising from legal rules or customary abnormalities to investigate fault and someone who does not have the ability to understand, or to blame, underage, and insignificant may also be blamed and accountable. This theory, which seeks to provide more support to the detriment of the 
people and to provide people with safety for abnormal and abusive behaviors and at the same time he was partly aligned with the traditional theory of fault and somewhat moderated, led to a reform in France in 1968 and the civil liability of people with mental disorders.

\section{Types of fault}

In the world of law, fault can be divided into different types. Sometimes it can be divided according to the spiritual element (intention) of the perpetrator (deliberate and unintentional guilty) Sometimes it can be divided into a material element (verb and verb) It is also possible to divide the fault based on the occupation and the social group in which the offender is located. (Fault in jobs and professional responsibility) (This division) is so obvious that no one, and even the legislator, cannot deny it. In this section, we will divide the types of faults, but it should be noted that it will only deal with the types that have practical effects.

\section{Regarding the material element (action, inaction)}

Sometimes there is a violation of the right or the financial with the present (oppression) and sometimes it has been forbidden to perform a task that the person has done (wastage). The legislator in articles 951 and 952 of the Civil Code recognizes oppression and wastage. Outside the territory of the contract, usually, the fault is due to the work done, because in social life and in the relations between people who do not link each other to each other, the principle is to leave the verb, because everyone should avoid losing to another. (Doroudian, 1370, p. 116) There is no doubt that doing verb can be considered a fault, because it often describes an abusive and ugly character for doing work. (Safai, 2010, p. 156) Therefore, there is no doubt that the subject of the error is the fault of the work, whether as loss or loss to another, is to blame.

The legislator also paid due attention to this and stated in Article 1 of the Civil Law Act of 1961: "Anyone who has no legal right to intentionally or as a result of accidental loss of life or health or property or liberty or reputation or commercial reputation or to any other right, Which is created in accordance with the law for individuals, causes damage that results in material or other harm to the person who is liable for the damage caused by his actions."

It should be noted that all instances of verbs are not necessary and the legislator has not done so, because in violation of criminal law, in which the principle of subsidiarity of offenses and penalties exists, there is a lack of such civil liability in the field of civil liability, because here, the custom and reasonable habit are one of the main criteria in this regard. It should also be noted that the purpose of the verb here is not merely a physical verb and includes credit (or legal) acts. 
In Islamic jurisprudence and Iranian law based on Imam's jurisprudence, unlike French law, there has never been any doubt as to the responsibility of a Tark's person. Because in the jurisprudence of the school of individualism there is no place and people are responsible towards each other, especially where the Tark is required to do something. Allah humbly says in his book:

$$
\text { 》كلكم راع و كلكم مسئول عن رعيتهش }
$$

In general, we can say that Tark is responsible for:

1. In the case of doing something as a legal assignment. For example: protecting a child, breastfeeding a child's mother when it is not possible for him to be fed by others, Helping a person at risk by taking immediate action or helping others or advising competent authorities, provided that there is no danger to the person or others. (Single article of the Penal Code to refuse to assist injured persons and to eliminate the dangers of life in 1974)

2. Sometimes an assignment is imposed on the person under the contract and leaving the assignment is the fault of the individual. Such as: a restaurant owner's obligation to prepare a guest meal, a loyal commitment to a transaction, or a customer to pay the price, a secure commitment to hold the financially deposited.

3. Anyone who creates a dishonest and unbelievable danger is obliged to inform others of it. For example, manufacturers should be informed of the potential risks of their products. This assignment has been approved in Imamieh jurisprudence in an irregular manner (alert).

4. Sometimes refusing to do something is a matter of indifference. For example, do not place a shield around the building project or be aware of the flaw of the wall and reposition it.

Therefore, there is no reason to believe that doing what a normal human being does is considered a fault, but not doing what the conventional human is supposed to make. The advantage of this division is that any current act of misconduct causing harm to another is considered a fault, but in the law of countries where the verb is considered to be the fault only if there is a legal or contractual obligation, the offender is only obliged to predict that the obligation is to be compensated for another.

\section{Job and professional fault}

In conveying a conception of fault with regard to the criticisms of the standard, it was believed that it would not be possible to establish a definite criterion for all people, but it should also be considered the culprit. In other words, belonging to an occupational and professional group will 
make a different measure about his fault towards others. Therefore, where the owners of the profession and profession carry out their occupation, they must be compared with the ordinary person of the same occupation and class, because having science and expertise prevents them from comparing them to their normal practice with their ordinary worker.

By definition of the fault, it was said that: The conventional behavior of humans will be the criterion for determining the fault, it is clear that the fault is a flexible concept and that a conventional human being will behave in that position and then will judge the realization of the fault. The general rule is that, in order to establish fault, they compare the behavior of a person with the general and unconventional general human behavior. However, this rule cannot apply to professional people.

In French law, job misconduct is also a disregard for job regulations, as is the case for other professionals. In relation to the owners of these businesses, two issues can be addressed; The first issue is whether their commitment is based on a contract, or is it a coercive one and, as a result of their fault, is a contractor or coercive? The problem arises from the fact that, in some cases, a doctor, lawyer, engineer, etc. are legally bound by the law to adhere to their trade rules and professions. So is it possible for the victim to ignore the contract and invoke the law.

The late Dr. Katouzian states: If the citation to the law of equilibrium and the order that the two parties have considered is inadequate, it has the right to invoke a contract or law, but in general, these blame must be considered contractual.

Some also believe that, if you want, you must be free to choose the basis of the lawsuit, unless you rely on strict liability to change the contractual or legal terms of the contractual liability. The other question about the responsibility of business owners is whether their commitment is a commitment or a commitment to a result? For example, medicine is committed to treating illness, and sick people also sign this treaty on trust, but the treatment is not effective and the patient is lost, to determine which doctor is responsible for the compensation for damage resulting from the breach of the treaty. Should he see what he has done? Has the patient recovered or committed to using all his knowledge and experience in this way? In the first case, when the patient dies, he is guilty of it, but in the second case, when the culprit is proven to be neglected or neglected or did not have the necessary skill.

In such cases, the magistrate must first acquire the true intention of the two parties, but, whenever there is no implication, it must consider the obligation of the ability of the business owners.

In such cases, the magistrate must first acquire the true intention of the two parties, but, whenever there is no implication, it must consider the obligation of the ability of the business owners.

So when the doctor takes care of the patient, it seems that he has been committed to the healing of the patient in the medical facilities. So if it is guilty that he is proven to be unwise in this 
way and does not conform to the behavior of the informed and reasonable physician, it is also in the obligation of a lawyer or legal counselor and a notary.

Conversely, in the case where the architect pledges to build a building with a particular resistance, his commitment follows the result. Because in his technique he is less involved in the external and hidden factors and can normally be trusted to achieve the desired result. So, if the building is destroyed, the architect will be guilty unless he proves that his work is not a failure and sudden and unpardonable pests have caused it.

\section{Breakdown of fault based on unpardonable fault level}

In ancient French law, following the Roman law, they ranked the fault in the field of contracts, and divided the unintentional fault into a very light, light and heavy. This division was criticized in the 18th century, and despite the fact that it was possible to assume that the unanimity of the blame was totally rejected by French new law, in fact, the distinction between the fault of light and very light was completely rejected, but the difference between the fault of light and heavy did not disappear. It should be noted, however, that the new French judicial procedure revived this division (the difference between light and heavy fault) and accepted the new legislature in some cases and including cases where the judicial procedure accepts this distinction as non-liability or limitation of liability.

In the definition of style fault it is said that:

"The fault is a guilty genre that a person does not commit with moderate prudence" (Safai, 2010, p. 160).

While it is said in a very light fault:

"It is a fault that a very cautious person does not commit it" (Safaee, 2009, p. 178).

There are several complains about the great fault, some of which are referred to here. In the definition of heavy fault, Carbenay says:

"The big blame is a blunder that, in the sense of lack of skill or serious neglect, is somewhat surprising. There is no intention of harm and nobody, but there are so many problems as if deliberately done "(Safaee, 2009, p. 180).

In his civil rights book, Mazoos, in the definition of heavy fault, states:

"The heavy fault is a fault that is neither deliberate nor voluntary, but obvious. The perpetrator did not want a loss or failure to execute the contract, but he behaved as if he had asked for it "(Safaee, 2009, p. 181).

The French judicial procedure has provided criteria for the detection and detection of a high level of fault: 
1 The obviousness of the fault, like the case in the ship, is placed next to the fabric packs.

2. The fundamental nature of the breached commitment, such as the delivery of the goods by the transport manager to the person who did not have the required position to receive it.

3. The probability of occurrence of a loss, such as failure to take the necessary measures by the transport manager to preserve food waste.

4. Lack of reasonable and expected care by professional and professional persons.

5. Repeat an offensive act, such as repeat theft, with trustworthy.

6. The significance and value of the damage incurred.

The French court in a judgment dated October 8 and 15, 1975, stated that sometimes a breach of an obligation to provide personal benefits in the field of contracts was a deliberate blame, although there was no intention of harming it.

\section{Dividing according to the spiritual element (deliberate and unintentional)}

The fault is deliberate if someone attempts to harm others, such as destroying a house or firing a torch to take revenge on the owner. Therefore, deliberately inaccurate work is carried out intentionally and the result of the intended purpose is committed.

Some believe that "A deliberate or criminal misconduct is an act without the permission of the perpetrator to commit harm to another and is not sufficient to predict the likelihood of harm." In order to enable the prosecutor to disclose the intentional conduct of the commission, the perpetrator must be tested verbally and, from the circumstances, obtain the motive of the subject in committing the act.

In French law, it is said about a deliberate or deceitful blame: The fault is when committed intentionally or intentionally is a deliberate, deceptive attempt on the part of "the will to seek a result" Of course, you should know that the intention of the felony is not intended to be harmful; Because it is not necessary to demand damages as it has come, it is enough that the sole purpose of providing it is personal gain.

Conversely, in an unintentional fault, one does not intend to harm another, but as a result of negligence and carelessness, he causes harm to him. If a driver drives due to acceleration or speeding, and causing damage to another car due to a collision, his fault is unintentional. This divorce does not make sense in terms of responsibility, since in both cases it must compensate for the losses caused by its work, but the distinction between deliberate and unintentional injuries has a practical effect:

1. It is compulsory for the prosecutor to investigate the intent and purpose of the misconduct, to ascertain whether he wanted to have an unpleasant incident or just wary, so his exploration is 
personal and related to the psychological state and the will of the error, but in the unintentional fault of the investigation, the judge and his assessment criterion have a certain face, since he compares the work with the standard human behavior in the event of an incident.

2. Damage insurance that is caused by accidental and negligent personal injury is possible, but no one can insure the damages he intentionally incurs. Such insurance not only puts the insurer in an unpredictable and dangerous situation, in the sense that it releases the insurer in harm to others, contrary to public order.

3. The condition of non-responsibility is primarily due to the unintentional fault, but no contractor cannot wipe out the responsibility of someone deliberately harmed by another. Enacting such a contractor to a conditional one, which sometimes can impose his will as he wants to resolve the contract, allows him to behave arbitrarily and to view him/herself in harm to others.

\section{Conditions, making intentional fault}

1- If we seek to express our intentional fault, we should give it a role that cannot be conquered through unintentional blame and incidents. Therefore, the intention of the perpetrator is that which is unique in relation to the intentional fault and justifies the distinction between the intentional faults of the unintentional fault. For this reason, it has been said that the intention is to have a unique mental state that is not comparable to the level of predictability. (Perl, 1995, 50) According to Holmes, intentional fault involves piety, misconduct and intent. According to him, in criminal law, misconduct and intent are simply cited to predict the occurrence of harm. Thus, in civil law, negligent harm with deliberate and deceptive intentional misconduct can be included in a philosophically integrated set that is organized in accordance with the amount of damage predictability.

2- $\quad$ Sometimes the continuation and repetition of a behavior with a high likelihood of causing a loss is due to the existence of a deliberate fault of this behavior as an act or an act having a high probability of injury caused by continuity and repetition. (Burnett, 2001, 491) In the case of Cunningham, plaintiffs have claimed that their employer contributed to the following: 1) Changing the direction of the chimney so that the soot is replaced by the exit into the factory and the work environment and the place where the workers were employed. 2) Turn on the ventilation device at some times 3) Harvesting warning labels from containers containing toxic substances 4) False statements about the nature of toxic substances 5) Wise refusal to provide safety equipment 6) The objection of objection regarding the unnecessary equipment and the risks associated with work in a particular factory, in this case, stated that: The employer's attitude has reached the level of a 
deliberate fault and repetition of the harmful act and its continuation indicates the employer's intentional fault. (Burnett, 2001, 491)

Therefore, deliberate intent leads to deliberate undesirable conduct, and the result of the work is the purpose and motive of the perpetrator. (Marti and Reno, p. 47) In other words, such a victim wants both an illegitimate means and a result of deliberate deception in the cases in which the perpetrator does not want to harm others, but disregards them.

\section{Examples, intentional fault}

In order to clarify the intentions of the intentional fault, it is necessary to note some important points extracted from the judicial process:

1. In intentional fault, it is necessary that the person asks for material or moral harm to one another and the intentional conduct of the verb is not sufficient. So if one throws his hands in the air to practice his work and his hand collides in another way, the guilt must not be deliberately counted.

2. If a person deliberately commits an act to one person and the other is harmed, the practice of the injured person is also intentional. In the US, in such cases, they are deliberately referred to as "transferred". For example, if someone firing another person to kill another person but firing another shot, the murder of this person is intentional, even though the perpetrator does not intend to kill you, but in the Islamic Penal Code, the perpetrator makes a mistake as soon as it is understood and takes the relative notion of intention.

3. Salaries consider a work that he or she is certain to be certain or that he is certain that he is going to be deliberate. For example, if a person, like a joker, intends to land another seat, he takes or overturns the seat of his seat, while he knows that his purpose sits down and falls to the ground, his intention is intentional. But if the chance to sit on the overturned chair is not near certainty, you should not consider it to be intentional. Therefore, in intentional fault, there must be an offense or purpose, or certainly the result of the act committed, even though the result has been exceeded and the damage incurred cannot be foreseen.

4. We know that tyrants and even maniacs and children are responsible for their actions and may commit the fault, but they cannot be taken into account for the purpose of distinguishing the intentional fault from unintentional into this absolute criterion. Their fault is deliberate if, in addition to the general conditions of intentional fault, one has to go through someone who has the power of determination. Therefore, the fault of these is in any case unpardonable, although formal conditions of intentional fault. 
5. However, it should be noted that the point of intentional fault is at the same pillar, which increases the amount of misconduct and prevents the prosecutor from blaming the crazy or unacceptable child.

\section{Intervention in contractual relationships}

A person who deliberately and illegally interferes with the economic interests of individuals in their business and their contractual relationships has committed an offense of interference with contractual relationships. This interference can take place in a variety of ways. Including incitement to violate a contract, persuade, compel or threaten to prevent the execution of a contract. This responsibility is especially important in two important contractual relationships. One of the most important cases is the imposition of liability on the part of a third party for deliberately incitement to violate contractual relations in the Lumely file. In this case, the petitioner signed a contract with an opera singer, and the reader agreed to not execute his contract with the petitioner anywhere else. This has been accepted by the public.

The other theater owner, who was competing with the theater and slipped his business down the slope, tempted the reader to cancel his contract and refrain from attending the theater in the remainder of the term and hire him. The reader also did this. The court held that the theater owner, in response to the claimant, was responsible for interfering in the contractual relationship and ordered him to assume responsibility and argued: "Justice requires that anyone who is wrongfully and unfairly entrusted with persuasion should be held responsible for the fulfillment of his obligations to the detriment of others, in order to avoid disturbing the legal relations of individuals."

\section{Illegal competition and conspiracy and collusion in disturbing another business}

The signs of a healthy economic market are the competition between manufacturers and suppliers of goods and services. This competition will balance the supply and demand, the quality of goods and services and the price, which will lead to economic prosperity. There are some cases in which a person is not able to compete in the market and goes out of the scene of the economic race. It is not because of the nature of the business of commerce and business, it is not the responsibility of any of its competitors. This lack of responsibility, of course, exists as long as the rival does not commit intentional fault. In other words, the existence of any malpractice that leads to harm to the unwanted person (whether it is intended to achieve a particular outcome or the likelihood of a near-probable occurrence of any harm) causes the person to be held responsible. Conspiracy to disturb another business 
It is said that no one has the right to sell and sell his goods or services and pretends to be the other. According to the Commercial Procedure Act of 1975, companies should not behave in their trade and transactions in such a way as to deceive others and to imagine that the goods and services of that other company. (Stuhmcke, 2001: 155). In this pseudo-crime, five elements can be imagined: 1. Trapping (Operation that deceives the trading party).

2. The perpetrator of this pseudo-offense must be a businessman and commit it in commercial transactions.

3. To direct and immediate customers or consumers of goods or services competing or sold.

4. Losses are foreseeable.

5. Has requested damages

6. Damage to the claimant

Occasionally, the competition is illegal, depriving others of certain job opportunities. This type of illegal competition, which is aimed at harming others, is in contrast to justice and fairness and causes individual liability. Examples of these responsibilities can be found in the Gender Alienation Act of 1975. (Cane, 1997: 157)

French courts in the second half of the twentieth century came to the conclusion that if the purpose in the element of the blame eventually leads to the creation of a liability arising from a pseudonym, then two issues or two other institutions that contribute to this goal should be considered and investigated. And these two are:

First: Contract defects from one of the Contracting Parties

Second: unfair competition

As a result of this, the French courts repeatedly concluded that, if necessary, the third person should be blamed and he is the one who either stimulates and encourages one of the parties to refrain from the implementation of the contract or compels him to violate the contract.

This occurs when a third party is first aware of the existence of the contract and, in the second; the conditional contract has the effect of preventing aggregation or incompatibility,

That is, a condition that does not provide the interests of the reader and at the same time it is possible that the third party does not have intent or bad intentions in the process to harm the other contracting party, that is the reader understands that he has neglected the contract with a clause or clause in a manner that does not provide his interests. But the other issue involves unfair competition, that is, blatant behaviors in trading and business affairs.

The French courts have called for the use of the term "Concurrence " as a means and way. To achieve order and discipline in the trading market, where courts are often forced to order the 
detainee to stop his actions to prevent the loss of the requester. The legal basis for entering this loss is the pseudo-crime that is being brought before the court.

This responsibility arises when it wants to prove that the competition has been unfair. The French court judgments on the above issue were very different and complex, and the only thing that the courts agreed on is the idea that diligent actions should be in contravention of commercial practices or purity in transactions.

On the other hand, on this idea, the courts agreed that if the behavior was unfair, whether this behavior was lacking intent to harm the party or not, does not affect the nature of the dispute and the outcome, and in any case Responsibility for the droid is imposed. For example, he claims that the droid has used his brand, which has led to the confusion of his customers. Therefore, the reader is guilty for any reason. It should be said that this is a violation of intellectual property rights. In this case, the element of fault is devoid of the agent or psychological content, that is, the psychic element, which is the intention to enter harm to another, may not be considered, and only attention to the question of fault in the court is considered.

In other cases, there are unfair behaviors in business that the court will inevitably seek to harm the rival, even if this behavior is not verifiable with bad intentions of a competitor's list of customers.

Of course, it is clear that there are not many local issues in place to clarify or declare all the complex rules and regulations, but achieving this result is enough to show; Referring to the general provisions of Article 2004 of the French Civil Code, as well as Article 1383, it is possible to say that certain solutions have been put in place in the course of the proceedings in order to coordinate with the content of the two articles of 2004-2005.

\section{Subreption}

Detection as one of the instances of intentional fault, as stated in Article 438 of the Civil Code, The following is an operation that deceives the parties to the transaction, In other words, it is a reflection of the imperfection that does not exist or to hide the defect in the property. It should be noted that the decree that is expected by the legislator is a departure from the conclusion of the contract in order to create a willingness to do so on the transaction side. Therefore, if during the execution of the contract of trickery and deception is used, the principle of the contract remains binding and it is only possible to return the enforcement acts instead.

According to some, "there is no need to prove the intention of harm, deliberate deception and intentional injuries are closely related." Because deception is routinely done so that fraudulent losses are exploited... It is likely that the deceiver believes that it is in the interest of both sides of 
the contract and he deceives and mistakes his victim in order to be satisfied with the contract. In deciding what is important, deception is intentional, not intentional harm. "

It should be recalled that subreption in the meaning of the term creates the right to terminate the transaction, which leads to a mistake in the subsidiary and non-physical description, but if the constraint causes a mistake in the substantive or intrinsic description of the contract, it would invalidate the transaction. In any case, subreption of a contract is one of the most important causes of intentional fault and its effects. In Article 391 of the Commercial Code, you can see an example of how to proceed with the contract. According to this article: "If the owner of the motor vehicle accepts and rents it without any reservation, it will not be accepted against the transport lender except in the case of deliberate deception or intent".

\section{The intentional blame for civil liability in Iranian and French law Article 2006 of the French Civil Code}

"The person is not only responsible for the damage caused by his actions, but is responsible for the actions of the persons who are responsible for them or for the objects and things that he possesses and keeps."

Addendum or amendment to Article 2006 of the French Civil Code includes:

Law of November 7, 1922

"Nevertheless, someone who takes possession of a building, or movable property in the direction, when or in part, from the base of which the fire occurs, he is liable to third parties due to the fire and losses incurred Unless it is proven that the fire was his fault or that he was responsible for the fault of those responsible for them." (Article 333 of the Iranian Civil Code can be cited in this regard).

\section{Law of November 7, 1922}

The ruling does not include the relationship between the landlord and the tenant who continues to be subject to the provisions of 1733 and 1734 of the French Civil Code.

Law No. 459-70 dated 4/6/1970, Articles 2 and 9

"Parents and children are jointly and severally liable for damage caused by minor children who live with them as long as the right of the province affects their children." (Law No. 305-2002 dated March 4, 2002)

- Master and employers are guarantors of damage caused by their crew and their staff to perform tasks assigned to them.

Teachers, craftsmen, are responsible for the damage done by their students and students, when the students and students are under their supervision. " 
Act of April 5, 1937

"The responsibility will be fulfilled unless the parent or artisan proves that they could not prevent the occurrence of such an act that would lead to liability."

Act of April 5, 1937

"In the case of teachers, the fault, negligence, neglect or neglect, which are brought against them because of the entry of losses, must be proved by the claimant or the plaintiff and in accordance with the general rules of law in the court. »

Article 1384 of the French Civil Code, which in fact expresses the responsibility of nonverb, can be said to be the most important law in relation to liability in the legal system of that country. In a comparative comparison, it is also necessary to refer to Iran's civil liability law, approved in 1961, Articles 7 to 12 and 13:

Article 7: "A person who maintains or cares for the insane or the spouse legally or in contravention of the contract shall, in the event of a fault in the maintenance or care, be liable for compensation for damage sustained by the insane or the underage And if it is unable to compensate for all or part of the damage, the loss will be compensated from the underage or the insane property, and in any case, the compensation must be made in such a way that it does not cause harm and disadvantage. "

Article 7 of the law of civil liability in accordance with Article 1384 of the Civil Liability Act and Law No. 549-70 dated 06/04/1970 France - Articles 2 and 9 of the law. It is not true and I believe that the rules of civil responsibility, protector or maintainer are underage in both countries. The reason for this is that the cited professors are probably not referring to the law of France dated April 5, 1937, which entered into Article 1384 of the civil law of that country. France's Act of 5 April 1937 states: "The responsibility will be fulfilled unless parents or craftsmen prove that they could not prevent the occurrence of such an act that would give rise to liability."

Article 12: "Employers who are subject to the Labor Law are responsible for compensating for damages incurred by the employees of the administration or their employees during or on the occasion of the work, unless it is established that all the precautions required by the circumstances of the case or the fact that they did so, it was still not possible to prevent harm to occur, the employer can refer to the damages importer if it is in accordance with the law, article 13: "Employers covered by Article 12 shall be obligated to indemnify all their employees and their administrative staff against losses incurred by the third party"

Result:

1. The law of liability arising from a non-verb or substitute liability in both countries is one and the same, but they provide different examples. 
2. Domains Examples and examples in Article 1384 of France are more extensive than the provisions of the Iranian civil liability law.

3. The French civil code in this regard considers it essential for a group, such as parents, professor and employer, to assume the sole responsibility or guilty of blame, and for another group, such as teachers, it is the responsibility of the accused to prove and prove it.

4- The civil law or civil liability law of Iran imposes responsibility for the authentication and proof of the denial.

5- Regarding the parent's responsibility for the comparison with Article 1384 of France, we can also refer to Article 1216 of the Iranian Civil Code. Both Iran and France, in their regulations, have the responsibility of parents or guardians to take precedence over insane or underage responsibility.

As already mentioned, the responsibility of parents and the responsibility of teachers about the people they oversee is not a real responsibility of "succession." Therefore, the most important responsibility of a person for the actions and actions of others is the responsibility of the principals and employers for workers and their employees or the responsibility of the employers and the chairmen for the actions of their agents or agents.

This type of responsibility comes about when there are three conditions:

1. There must be a "bonding" relationship between the person whose actions harm the plaintiff and the wanted person with the person who will be called. Most French lawyers believe that such a connection is necessarily in the "recruitment" issue, but in some cases and elsewhere, this relationship must exist.

2. The employer is liable or may be liable if there are "normal" conditions for the liability of the worker or his employee or his agent and is acceptable and this means that the action of the agent or his agent has created a "pseudo-offense".

3. An agent or agent who has entered into a marriage contraption must take such action and action in the course of the work he has been entrusted to him by the employer.

It's also seen in Camella's law, "On Employment."

However, the courts are wandering and flogging who is responsible for cases in which the agent or agent abuses in the performance of his occupation or in the exercise of his duties.

Given all the complexity of the problem that is mentioned above and is seen in practice, it is important to mention a very important point:

"The burden of proving non-liability lies with the employer." 
If the three conditions mentioned are obtained and realized, the employer is responsible to the person in charge because he cannot be held liable by "proof of non-fault" and not by the "major force factor".

While over the past hundred years the French courts have held responsibility for the "successor" to the employer, the Supreme Court of France has instead stated:

"The worker or the employer is responsible, with the employer, implicitly, that the worker or the agent himself has committed the fault."

It is apparent from the French Supreme Court that the scope of the protection of workers and agents has become more limited in the course of their work and employment.

The controversy is responsible, meaning that the injured person can go to each of the parties and bring him to the dispute.

\section{Article 334 of the Civil Code of Iran, in comparison with Article 2007 of the French Civil Code}

Article 334 of Iranian Civil Code:

"The owner or trapper of the animal is not responsible for the damage that comes from the area of the animal unless it is a fault in keeping the animal, but in any event, if the animal is harmed by the act of causing one's cause, the agent will be responsible for the damage sustained."

Article 1385 French Civil Code:

"The owner of the animal or animal who owns and uses the animal is responsible for the damage caused to the animal, whether the animal is under his control or whether he has been missing or fleeing . »

Under Article 334 of the Iranian Civil Code, the liability of the owner or trap of the animal is conditional and binding, and the French legislature, under Article 2007 of the French Civil Code, has taken responsibility for the owner or owner of the animal as absolute responsibility, or in other words, sole responsibility. As a result, according to Iranian law, the plaintiff or the claimant must prove the fault of the owner or the landlord, because the principle is based on the non-responsibility of the named ones.

5-2-5. Article 333 of the Civil Code of Iran, in comparison with Article 2008 of the French Civil Code

Article 333 of Iranian Civil Code:

"The owner of the wall or the building, or the factory, is responsible for the damage caused by its destruction, provided that the failure is due to a defect that the owner has been aware of or has been made of his lack of care."

Article 1386 French Civil Code: 
"If the building collapses and the losses caused by the owner's fault in maintaining it or due to a defect in the building, the owner is responsible for the damage that comes from its destruction and destruction,".

Responsibility in the law of both countries is the responsibility of the objects, with the difference that the legislator has assumed the fault of the owner in French law, but in Iran's civil law, the owner of the contingent and obligated owner is the owner of the defect or lack of care of the owner.

\section{Article 490 of Iranian Civil Code in comparison with Article 1733 of the French Civil Code}

The tenant, in accordance with Sections 1 and 2 of Article 490 of the Civil Code, shall treat the same tribute in a manner that is customary and not violate and apply the same piece of furniture for the same consumption as is provided for in the lease, and if it is not determined in the interest of the intended purpose which is deduced from the circumstances and the law makes it clear that the tenant is not guarantor of the same tent if the same tribute without his or her possessions is wholly or partially lost, will not be responsible. However, if the tenant is subject to a violation or violation, it is a guarantor, although the defect has not been obtained as a result of the violation or violation.

There is a general difference between the two laws of Iran and France:

In case of wearing the same footwear, Napoleon's Code of Conduct is legally permitted, and it stipulates that the Tenant is liable for the damage caused by the fire, unless proving that

1. Fire is the result of accidents that are beyond their control

2. It is caused by a defect in the building.

3. Or the fire from the neighboring house has been leased to the property.

The French Court of Justice has decided that the reasons for the cessation of the obligation contained in Article 1733 of the Napoleonic Code are quite limited and limited to the same threefold direction. Because the principle is legal, expressing that the fire is often caused by the occupation of the locus. Therefore, in accordance with the foregoing, in cases where the cause of the fire is unknown or that the tenant cannot prove by proving the positive and direct reasons for the failure of his obligation as prescribed by law, he shall be liable for the damage caused by fire and it must compensate for the losses incurred and, as long as the building is not restored and the landlord is deprived of its income, the tenant is required to pay the damages.

As it is seen, French law imposes a very heavy obligation on tenants and, as a result, tenants usually insure themselves against such incidents.

\section{Conclusion}


1) The fault is divided into various forms. Sometimes, based on the material element (verb or abstract), it is sometimes also divided according to the spiritual element (deliberate and inanimate). Classification of the fault based on the degree of unintentional fault, occupational regimes, etc. is also a common practice, each of which has practical effects.

2) In the context of intentional fault, attention is drawn to its essential conditions, including the intention to harm others in a deliberate fault. It is easy to distinguish this evil intention on the basis of examples and examples of this kind of fault. Sometimes the gravity of the fault is made and the circumstances of the occurrence of damage to the emirs are to detect intentional fault.

3. The criterion for the recognition of the fault is the custom, and the instances identified by the legislator are also allegorical examples, and since the purpose of civil liability is compensation, and not the punishment of committing the criterion of guilty is a standard criterion. In determining the fault, the behavior of a conventional person is considered, and with the acceptance of this underage and the insane is also considered to be responsible under the circumstances. Because their behavior is measured by the conventional human being who has distinctness and will.

4) In many legal systems of the world, responsibility is based on guilt. In legal systems, such as the French legal system, liability is due to intent, intentional and fault-based incident. In some cases, in this legal system, absolute responsibility (without fault) is accepted. In Islamic law, in all cases, no bases have been used and in Iranian law, in accordance with the provisions of a civil liability law, there is a fault-based liability, which, of course, has no effect on the material misstatement of civil law, including article 328. Therefore, it seems that the article of a civil liability law sets out a general principle that does not preclude the establishment of absolute responsibility by the community.

5) Sometimes the fault of one person causes loss of the responsibility of the subject. According to Article 7 of the Civil Liability Law, if the guardian or guardian of the underage and the insane has failed to keep them and commit a fault, the responsible person will be liable for the compensation; in fact, the responsibility based on the fault in this regard is preceded by absolute responsibility (minor and unnecessary liability).

6) The fault in compensation is also unaffected. In this sense, the court may, in accordance with Article 4 of the Civil Liability Act, reduce the amount of damages to it. Therefore, in order to resolve the apparent conflict between some of the rules, it is desirable to determine the basis of responsibility by the legislator and it seems that the best approach is solidarity of responsibility based on a single fault.

\section{Suggests}


The definitions of blame for civil liability are without personal fault, and it is better to take into account the critique of the standard of fault and the conventional and reasonable human being, the personal fault and the type of both in this definition.

Apart from the lack of due attention of the legislator to the use of instances of fault and the existence of legal effects in some of these terms (neglect, recklessness) It would be better if Iran's legislator, like the French judicial system, classifies and explains cases that clearly create civil responsibility, as well as their frameworks. According to my study in this study, the following results were obtained: French law, as well as English law, is much more comprehensive in terms of pseudocases, what we see in Iran's law is less, and the legislator deals only with civil liability issues in just 16 articles, which reflects on this issue, because the rules of civil liability apart from the payment of damages or compensation and compensation for losses, or any other name you want to apply, are rules for the protection of human dignity and integrity. Man is a civilian creature and his rights lie in the nature and nature and nature that if he gets these rights, he will suffer civilian death.

Today, civil liability rules are examined in all countries as part of the rights of obligations. The civil liability law system is changing, developing and upgrading in most countries. This is due to changes in society, new lifestyles and technological innovations. Such as damages caused by new technologies, alternative energies, defective and incomplete goods, and so on.

Unfortunately, this branch or branch of the law in our country has been dramatically degraded towards the European countries and even what we have as civil liability rules in our country's laws and regulations is not seriously and fundamentally used in the courts. There are scattered rules and regulations on civil liability that are sometimes neglected by honorable professors, judges, lawyers and students. All these regulations must be collected and incorporated into a specific section of Iran's civil law as a rights obligation. The civil law of our country, as mentioned above, lacks a section called "the law of obligations", which should be added to the current civil law through new legislative amendments. A point that has been neglected, especially in our civil liability system, is the story of the sole responsibility and expansion of its scope and scope. Finding the guilty person and compensating the injured person should not merely seek the element of fault, because with complex technologies, it is sometimes impossible to find the element of fault. 


\title{
Revisão, falha deliberada no campo da responsabilidade civil nas leis iraniana e francesa
}

\begin{abstract}
Resumo
A jurisprudência e as leis iranianas são baseadas no princípio da responsabilidade pela humilhação, sendo a responsabilidade absoluta já familiarizada. Sendo assim, há a necessidade por uma legislação mais clara. O humilhado é entendido como a vítima ou como o desperdício do comportamento humano nas circunstâncias externas ao incidente. Além disso, ao aceitar a ideia de um tipo de humilhação pelo povo iraniano ou francês, a falta de claro ponto irracional como maníacos também é responsável, dependendo da circunstância. A humilhação é dividida em variedades diferentes, às vezes baseada no elemento material (ação e omissão), às vezes baseada no elemento espiritual (desprezo intencional e não intencional). Devido à humilhação deliberada no contexto das condições básicas, é importante reconhecer a intenção de infligir intencionalmente a humilhação. Às vezes, falhas graves cometidas com presumida circunstância de perda são suficientes para a detecção de humilhação deliberada. As ferramentas criaram a perda; a responsabilidade é com as ferramentas convencionais e originais com a comunidade na criação de perdas, a responsabilidade de dividir deve estar na taxa de efeito das ferramentas. O artigo 526 do F.M.I. é mero observador de que as ferramentas que afetam são iguais. Motivo de força maior ou responsabilidade absoluta, como raiva, não é responsabilidade, mas assume responsabilidade com base em humilhação e desprezo.
\end{abstract}

Palavras-chave: Responsabilidade civil, humilhação, humilhação deliberada, Responsabilidade baseada em humilhação

\section{References}

1. Badini, Hasan. (2009). Civil liability booklet, Master's degree, Police Department, Faculty of Law and Political Science, University of Tehran.

2. Badini, Hasan. (2010). A Critical Attitude to the Standard and Mean Criterion for the Determination of the Blame for Civil Responsibility, Journal of Law, Faculty of Law and Political Science, Volume 4, Issue 1.

3. Baker, Tom- Brulhartt Vincent and Their Colleague. (2005). Tort Law and Liability Insurance. vol 16, Springer wien, First ed.

4. Civil Code of the Islamic Republic of Iran

5. Curry, Paniel, J. (1997). The Court of Appeals of Maryland Limits the Applicability of The Doctorin of Transferred in Intent, 27 u. BaIt. L. Rev 167, Fall.

6. Darabpour, Mehrab. (2008). Outside Contract, Majd Assembly of Science and Culture, First Edition.

7. Edwards, Linda L- Edwards, Stanley- Kirttley Wells Particia .(2009). Tort Law, Pelmal Cengage Learning, 4th ed.

8. French Civil Code (Napoleon Code)

9. Garner A. Bryan .(2001).Black's law Dictionary, Thomson west publishing co- 3th ed. 
10. Hylton .Keith W. (2009). Intent in Tort Law, Boston University School of Law, Working Paper No 9- 21, April.

11. J. Curry, Daniel .(1997). The court of appeats of Maryland limits the applicability of the doctoring of transferred intent, 27U, Balt 1.rev, 167, fall.

12. Katouzian, Naser. (2009). The Transformation of the Concept of Fault in Civil Civic Rights, Journal of Law, Faculty of Law, University of Tehran, Volume 39, Issue 1.

13. Katouzin, Naser. (2014). Civil liability, Public Joint Stock Company, Vol. 1, 11th Edition.

14. Nasiri, Mostafa. (2008). The role of the blame for civil responsibility, Judges monthly.

15. Novin, Parviz. (2013). Civil Law 4, Adoptive Civic Responsibility (Comparative Responsibility of Iran, France, England), First Edition, Ganj Danesh Publications, Tehran.

16. Safaee, Seyyed Hassan, Rahimi, Habibollah. (2015). Civil liability (out-of-contract requirements), Publications.

17. Safarian, Mehdi. (2013). The role of deliberate blame on civil responsibility, Jungle Publishing, First edition.

18. Schroeder, Thomas D. (1983). Workers compensation: Expanding the international Tort Exception to Include Williful, Wanton and Reckless Employmer Misconduct, No 58, Tre Dame L. Rev. 890.

Trabalho recebido em 25 de janeiro de 2019

Aceito em 12 de março de 2019 